Vol 2, No.1 2018 p. $12-24$

Available online at:

http://jurnal.upnyk.ac.id/index.php./JMEL

\title{
Evaluasi Kelayakan Teknis Penambangan Rakyat Batugamping Desa Sendangsari, Kecamatan Pengasih, Kabupaten Kulon Progo
}

\author{
Dian Hudawan Santoso, Andi Sungkowo, Muammar Gomareuzzaman \\ Jurusan Teknik Lingkungan, Fakultas Teknologi Mineral, UPN "Veteran" Yogyakarta, \\ Jl. SWK 104 (Lingkar Utara), Condongcatur, Yogyakarta, 55283 \\ E-mail korespondensi: hudageo@gmail.com
}

\begin{abstract}
ABSTRAK
Kegiatan penambangan rakyat di Kabupaten Kulon Progo dilakukan tanpa didahului kajian kelayakan teknis sehingga berpotensi mengakibatkan kerusakan lahan dan kecelakaan bagi penambang dan masyarakat sekitar. Kegiatan penambangan batugamping di Kabupten Kulonprogo banyak dilakukan di Desa Sendangsari, Kecamatan Pengasih. Tujuan penelitian ini adalah untuk mengetahui kelayakan teknis penambangan rakyat dengan jenis material batugamping. Kelayakan teknis diharapkan dapat menjadi pertimbangan pemerintah dalam usaha penetapan Wilayah Pertambangan Rakyat khususnya komoditas batugamping di daerah penelitian. Penelitian yang dilakukan merupakan jenis penelitian survei dan pemetaan. Metode yang digunakan penelitian ini adalah metode survey dan pemetaan, wawancara serta analisis pengharkatan (skoring). Hasil penelitian menunjukkan bahwa berdasarkan evaluasi, terdapat 4 lokasi penambangan batugamping di daerah penelitian dimana satu diantaranya sudah tidak aktif sedangkan tiga lokasi lainnya masih aktif. Kegiatan penambangan yang masih aktif tersebut terdapat di Dusun Paingan dan Dusun Secang. Secara kelayakan teknis pada ke tiga lokasi kegiatan penambangan batugamping dinyatakan kurang layak secara teknis. Kata Kunci: Pertambangan Rakyat, Kelayakan Teknis, Batugamping
\end{abstract}

\begin{abstract}
Community mining activities in Kulonprogo Regency are conducted without a pre-requisite technical feasibility study resulting in the potential to cause land and accident damage to miners and communities. Limestone mining activities in Kulon Progo Regency are mostly done in Sendangsari Village, Sub District of Pengasih. The main purpose of this research is to know the technical feasibility of people mining of sand. By knowing technical feasibility later it is expected to be the government's consideration in determining the Mining Area of the Commuity especially the limestone commodity in the research area. Research conducted by survey and mapping research. The analysis of the technical feasibility of people mining for sand is done by the method of scoring. The results showed that based on the evaluation, there are 4 limestone mining sites in the research area where one of them is not active while the other three are still active. The active mining activities are located in Dusun Paingan and Secang. The technical feasibility of the three limestone mining sites is considered technically feasible.
\end{abstract}

Keywords: Community Mining; Technical Advisability; Limestone 


\section{PENDAhuluan}

Kabupaten Kulon Progo merupakan daerah yang memiliki cadangan bahan tambang yang cukup besar setelah Kabupaten Gunungkidul. Bahan tambang batuan dan tanah merupakan bahan baku yang penting dalam pembangunan, diantaranya sebagai bahan bangunan dan bahan baku dalam industri (Noor, 2006). Usaha penambangan bahan tambang batuan ini telah memberikan sumbangan yang tidak kecil terhadap pendapatan daerah dan terciptanya lapangan kerja. Pengelolaan pertambangan bahan tambang ini khususnya penambangan rakyat masih sangat memprihatinkan. Sebagian besar usaha penambangan rakyat tidak memperhatikan tata lingkungan baik pada saat penambangan masih beroperasi dan pada saat sudah tidak beroperasi, sehingga salah satu akibatnya dapat mengakibatkan perubahan bentuk lahan dan berpotensi menimbulkan dampak negatif terhadap lingkungan seperti terjadinya gerakan massa tanah dan/atau batuan, terutama lingkungan sekitar area penambangan (Sulton, 2011).

Kegiatan penambangan bahan tambang di Kabupaten Kulon Progo dilakukan oleh masyarakat tanpa didahului kajian teknis penambangan yang baik sehingga hal tersebut dapat berpotensi mengakibatkan potensi kerugian dan kerusakan lahan (Soemarwoto, 2001). Kerusakan lahan tersebut disebabkan akibat kegiatan penambangan rakyat yang dilakukan tanpa adanya perencanaan dan perbaikan lahan setelah penambangan yang baik. Perubahan lahan pasca tambang dapat berpotensi dalam mempengaruhi kelestarian fungsi lingkungan hidup. Kelestarian fungsi lingkungan hidup yang terganggu keseimbangannya dapat berdampak pada kenaikan suhu lokal, penurunan fungsi tanah sebagai media tanam, terganggunya tatanan hidrologis, terjadi erosi dan rentan terjadi gerakan massa tanah (Soerjani, dkk. 1987). Perubahan lahan yang akan berdampak pada kerusakan lahan tersebut perlu dilakukan reklamasi lahan sebagai tindakan pelestarian fungsi lingkungan agar tidak terjadi kerusakan lebih lanjut (Arif, 2007).

Kegiatan penambangan batugamping banyak terdapat di Desa Sendangsari, Kecamatan Pengasih, Kabupaten Kulonprogo. Berdasarkan pengamatan eksisting di lapangan terdapat 4 lokasi penambangan batugamping, dimana 3 kegiatan penambangan aktif dan satu tidak aktif. Lokasi kegiatan penambangan tersebut diantaranya adalah 2 lokasi di Dusun Paingan, Desa Sendangsari, Kecamatan Pengasih dan 2 lokasi di Dusun Secang, Desa Sendangsari, Kecamatan Pengasih, Kabupaten Kulon Progo.

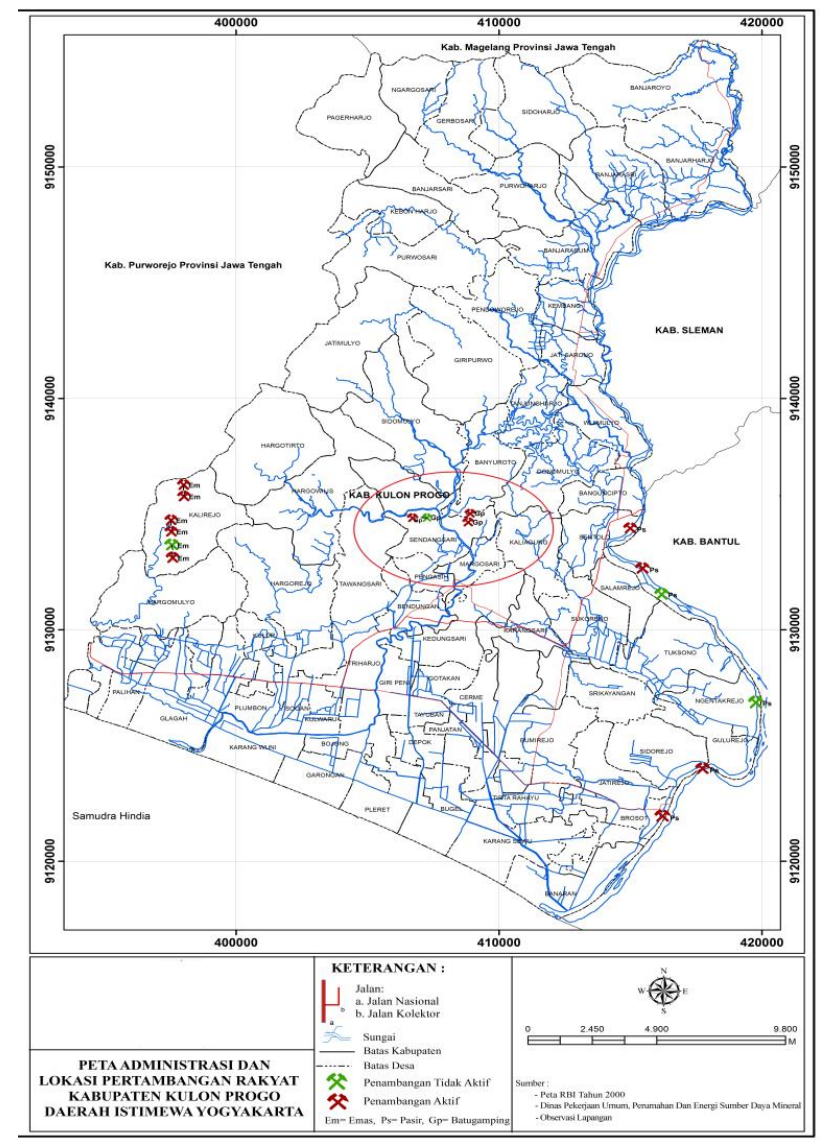

Gambar 1. Peta Lokasi kegiatan Penambangan Rakyat Batugamping Desa Sendangsari, Kecamatan Pengasih, Kabupaten Kulonprogo 
Dengan adanya kegiatan penambangan pasir batugamping yang dilakukan oleh rakyat maka sangat perlu sekali diteliti tentang bagaimana teknis penambangan batugamping yang selama ini dilakukan oleh para penambang. Teknis penambangan akan sangat mempengaruhi bagaimana tingkat keamanan para penambang pada saat menambang, sebab kegiatan penambangan batugamping jika tidak dilakukan dengan benar dapat berpotensi merusak lingkungan dan menimbulkan kerugian bagi para penambang dan masyarakat sekitarnya. Tujuan utama dari penelitian ini adalah mengetahui kelayakan teknis penambangan rakyat batugamping di lokasi penelitian. Tingkat kelayakan teknis penambangan batugamping ini diharapkan dapat dijadikan masukan bagi para penambang, stakeholder ataupun pemerintah untuk pengelolaan lebih baik di masa depan.

\section{METODOLOGI}

Penelitian yang dilakukan merupakan jenis penelitian survei dan pemetaan. Pengertian survei adalah salah satu teknis riset untuk mengkaji fakta-fakta di lapangan dengan teliti secara deskriptif, berdasarkan pemeriksaan dan pengukuran (Sugiyono, 2017). Pengertian pemetaan adalah kegiatan memindahkan unsur-unsur karakteristik lingkungan di lapangan ke dalam peta dasar dalam bentuk titik, garis dan area. Peta dasar yang digunakan dalam penelitian ini adalah peta topografi dengan skala menyesuaikan dengan kondisi medan (hasil pemetaan langsung di lapangan) mengacu peta skala $1: 25.000$.

Analisis kelayakan teknis pertambangan rakyat batugamping dilakukan dengan metode pengharkatan (rating). Pengharkatan dilakukan terhadap parameter kelayakan teknis yang kemudian dilakukan pembagian klasifikasi setiap kelayakan. Klasifikasi dibuat dengan menentukan lebar interval (julat) dengan rumus:

$$
i=\frac{\sum a-\sum b}{n}
$$

Keterangan :

$\mathrm{i} \quad=$ Lebar interval (julat)

$\sum a=$ jumlah harkat tertinggi : jumlah parameter

$\sum b=$ jumlah harkat terendah : jumlah parameter

$\mathrm{n} \quad=$ Jumlah Kelas

Analisis kelayakan teknis dilakukan berdasarkan pada tingkat kerusakan lingkungan dan upaya pengelolaan teknis yang telah dilakukan oleh pelaku kegiatan penambangan batugamping di daerah penelitian. Metode dilakukan dengan identifikasi ada atau tidaknya upaya pengelolaan teknis dan kondisi lahan pasca tambang, terhadap fungsi lahan yang diperuntukan sebagai lahan pertanian/perkebunan dan proses degradasi lahan (erosi, gerakan massa tanah dan/atau batuan). Hasil identifikasi dapat digunakan untuk menentukan pilihan penerapan pengelolaan teknis selanjutnya.

\section{1) Tahap Pra Pertambangan}

a) Rencana dan Desain Penambangan

Rencana dan desain penambangan merupakan salah satu faktor teknis yang sangat penting. Rencana dan desain penambangan sangat diperlukan dalam mengetahui langkah-langkah atau teknis dalam proses penambangan yang akan dilakukan. Apabila rencana desain tidak ada maka dapat dipastikan di dalam proses menambang dapat menimbulkan dampak negatif baik yang bersifat teknis, keamanan keselamatan kerja, serta bagi lingkungan sehingga kegiatan penambangan diberi harkat 1. Sedangkan kegiatan penambangan yang sudah memiliki perencanaan dan desain menunjukkan bahwa kegiatan penambangan sudah mempertimbangkan kondisi lingkungan sekitar sehingga dampak negatif dari kegiatan penambangan dapat diminimalisir dan diberi harkat 3.

Tabel 1. Kategori \& Harkat Rencana dan Desain Penambangan

\begin{tabular}{lllc}
\hline No & \multicolumn{1}{c}{ Rencana dan desain penambangan } & Kategori & Harkat \\
\hline 1 & Tidak & Buruk & 1 \\
2 & Ada tetapi tidak tertulis & Sedang & 2 \\
3 & Ada & Baik & 3 \\
\hline
\end{tabular}

b) Kekerasan Batuan

Kekerasan Batuan (bahan galian) identik dengan Kuat Tekan Batuan Utuh. Semakin besar nilainya maka akan semakin baik dan diberi harkat 5, karena semakin keras suatu batuan maka ketika dilakukan penambangan potensi terjadinya gerak massa batuan akan semakin kecil. Jika potensi gerakan massa batuan kecil dampak negatif seperti keruntuhan batuan bagi penambang maupun rumah yang ada di sekitarnya dapat dihindari. 
Tabel 2. Kategori \& Harkat Kekerasan Batuan

\begin{tabular}{llll}
\hline No & $\begin{array}{l}\text { Kekerasan Batuan } \\
\text { (UCS }- \text { MPA) }\end{array}$ & Kategori & Harkat \\
\hline 1. & $<5$ & Sangat Buruk & 1 \\
2. & $5-25$ & Buruk & 2 \\
3. & $25-50$ & Sedang & 3 \\
4. & $50-100$ & Baik & 4 \\
5. & $>100$ & Sangat baik & 5 \\
\hline
\end{tabular}

c) Jarak lokasi penambangan terhadap mata air

Jarak terhadap mata air merupakan upaya perlindungan terhadap sumber air yang digunakan masyarakat. Kegiatan penambangan yang dilakukan di perbukitan sering dijumpai mataair. Hal ini disebabkan karena bukit merupakan daerah imbuhan dan menjadi sumber air bagi masyarakat sekitar, sehingga perlindungan mataair dari kegiatan penambangan sangat penting untuk dilakukan. Semakin jauh kegitan penambangan dari mataair dan daerah imbuhan maka akan semakin baik dan diberi harkat 3. Sedangkan kegiatan pertambangan yang semakin dekat dengan mata air dan daerah imbuhan akan bernilai buruk dan diberi harkat 1.

Tabel 3. Kategori \& Harkat Jarak Lokasi Penambangan Terhadap Mata Air

\begin{tabular}{llll}
\hline No & Jarak terhadap mata air $(\mathbf{m})$ & Kategori & Harkat \\
\hline 1 & $<250$ & Buruk & 1 \\
2 & $250-500$ & Sedang & 2 \\
3 & $>500$ & Baik & 3 \\
\hline
\end{tabular}

d) Jarak lokasi penambangan terhadap permukiman penduduk

Jarak terhadap permukiman digunakan untuk meminimalisir terjadinya dampak negatif akibat kegiatan penambangan yang merugikan masyarakat, misalnya gerakan massa batuan dan/atau tanah. Semakin jauh jarak lokasi kegiatan penambangan dengan permukiman maka semakin aman dan jika dinilai dari aspek estetika dan kesehatan masyarakat juga semakin baik. Dengan demikian semakin jauh jarak lokasi penambangan dengan permukiman diberi harkat 3 sedangkan semakin dekat jarak lokasi penambangan dengan permukiman diberi harkat 1. Jarak yang digunakan dalam parameter ini dikhususkan untuk kegaitan penambangan yang tidak menggunakan bahan peledak. Apabila dalam menambang menggunakan bahan peledak maka jaraknya seharusnya akan semakin jauh hingga mencapai minimal 1-2 $\mathrm{km}$.

Tabel 4. Kategori \& Harkat Jarak Lokasi Penambangan Terhadap Permukiman Penduduk

\begin{tabular}{cccc}
\hline No & $\begin{array}{c}\text { Jarak terhadap } \\
\text { permukian penduduk }(\mathbf{m})\end{array}$ & Kategori & Harkat \\
\hline 1 & $<500$ & Buruk & 1 \\
2 & $500-1000$ & Sedang & 2 \\
3 & $>1000$ & Baik & 3 \\
\hline
\end{tabular}

\section{2) Tahap Proses Pertambangan}

a) Jenis peralatan penambangan

Jenis peralatan merupakan teknis penambangan yang harus sesuai dengan potensinya. Kegiatan penambangan rakyat akan lebih baik menggunakan peralatan penambangan yang manual. Hal ini berkaitan dengan potensi material tambang yang terbatas sehingga mendukung kelestarian lingkungan. Dengan demikian, kegiatan penambangan yang memakai peralatan manual maka diberi harkat 3 dan yang memakai alat mesin diberi harkat 1 .

Tabel 5. Kategori \& Harkat Jenis Peralatan Penambangan

\begin{tabular}{llll}
\hline No & Jenis peralatan penambangan & Kategori & Harkat \\
\hline 1 & Mekanis & Buruk & 1 \\
2 & Manual dan mekanis & Sedang & 2 \\
3 & Manual & Baik & 3 \\
\hline
\end{tabular}

b) Cara Penggalian

Cara penggalian kegiatan penambangan rakyat sangat berkaitan dengan K3. Cara penggalian sebaiknya dilakukan dengan memotong tebing. Memotong tebing lebih dianjurkan karena stabilitas lereng akan lebih terkontrol sehingga 
tidak menimbulkan runtuhan secara tiba-tiba. Stabilitas lereng akan lebih terlihat sehingga meminimalisir terjadinya kecelakaan kerja. Apabila cara penggalian dilakukan dengan membuat lobang galian bahkan dengan cara peledakan maka sewaktu-waktu dapat terjadi runtuhan yang dapat merugikan penambang bahkan lingkungan sekitar. Dengan demikian cara penggalian dengan memotong tebing diberi harkat 3 sedangkan yang menggunakan peledakan diberi harkat 1 .

Tabel 6. Kategori \& Harkat Cara Penggalian

\begin{tabular}{llll}
\hline No & \multicolumn{1}{c}{ Cara Penggalian } & Kategori & Harkat \\
& & & \\
\hline 1 & $\begin{array}{l}\text { Memotong tebing dengan manual, peledakan dan } \\
\text { mekanis }\end{array}$ & Buruk & 1 \\
2 & Memotong tebing dengan manual dan peledakan & Sedang & 2 \\
3 & Memotong tebing dengan manual & Baik & 3 \\
\hline
\end{tabular}

c) Relief dasar galian

Dasar galian adalah permukaan dasar lubang galian yang umumnya tidak pernah rata, karena selalu terdapat tumpukan atau onggokan material sisa galian dan dapat menyulitkan pemanfaatan lahan sesuai peruntukannya sehingga semakin dalam relief dasar galian, maka akan semakin buruk dan diberi harkat 1. Semakin kecil reliefnya maka semakin baik dan diberi harkat 3 karena semakin kecil relief rekalamasi dapat dilakukan sesuai dengan RTRW (Rencana Tata Ruang Wilayah) dan kondisi lingkungan tidak akan menjadi daerah yang tandus tanpa upaya reklamasi pascatambang.

Tabel 7. Kategori \& Harkat Relief Dasar Galian

\begin{tabular}{llll}
\hline No & Relief Dasar Galian & Kriteria & Harkat \\
\hline 1 & $\begin{array}{l}\text { Buruk, bila batas kedalaman > 1 m dibawah ketinggian } \\
\text { topografi terendah sekitarnya }\end{array}$ & Buruk & 1 \\
2 & $\begin{array}{l}\text { Sedang, bila batas kedalaman galian terendah 0 - 1 m } \\
\text { dibawah ketinggian topografi terendah sekitarnya }\end{array}$ & Sedang & 2 \\
3 & $\begin{array}{l}\text { Baik, bila batas kedalaman galian sama dengan } \\
\text { ketinggian topografi terendah sekitarnya }\end{array}$ & Baik & 3 \\
\hline
\end{tabular}

d) Perkembangan Erosi

Erosi merupakan perpindahan massa tanah akibat adanya aliran permukaan. Aliran permukaan akan terjadi lebih cepat ketika permukaan tanah di atasnya terganggu dan tidak terdapat vegetasi penutup. Adanya erosi dapat terjadi secara alami sehingga jika ada kegiatan penambangan akan semakin mempercepat perkembangan erosinya.

Tabel 8. Kategori \& Harkat Perkembangan Erosi Daerah Bukit

\begin{tabular}{llll}
\hline No & \multicolumn{1}{c}{ Tingkat Erosi } & Kategori & Harkat \\
\hline 1 & $\begin{array}{l}\text { Terjadi gully erosion dengan alur permukaan lebar dan dalam } \\
\text { yaitu lebar }>30 \mathrm{~cm} \text { dan dalam }>25 \mathrm{~cm} \text {, butiran tanah sangat } \\
\text { mudah lepas }\end{array}$ & Buruk & 1 \\
2 & $\begin{array}{l}\text { Terjadi rill erosion alur yang terjadi masih sempit dan dangkal } \\
\text { yaitu lebar }<30 \mathrm{~cm} \text { dan dalam }>25 \mathrm{~cm} \text {, butiran tanah sangat } \\
\text { mudah lepas. } \\
\text { Terjadi sheet erosion di permukaan, butiran anah sangat sukar } \\
\text { lepas dan kehilangan tanah relative seragam }\end{array}$ & Bedang & 2 \\
\hline
\end{tabular}

e) Perlakuan terhadap tanah penutup

Tanah penutup merupakan tanah awal sebelum dilakukan penambangan yang kondisinya telah lapuk dan relatif berkembang. Kondisi tanah penutup awal merupakan tanah yang mempunyai potensi yang subur.

Adanya keberadaan tanah penutup yang disimpan akan menjamin adanya pemanfaatan penggunaan yang lain sehingga memiliki nilai yang baik.

Tabel 9. Kategori \& Harkat Perlakuan Terhadap Tanah Penutup

\begin{tabular}{llll}
\hline No. & \multicolumn{1}{c}{ Perlakuan terhadap Kondisi Tanah Penutup } & Kategori & Harkat \\
\hline 1 & Hilang atau di buang & Buruk & 1 \\
2 & Langsung dipakai untuk peruntukkan lain & Sedang & 2 \\
3 & Disimpan untuk reklamasi & Baik & 3 \\
\hline
\end{tabular}


f) Pemanfaatan bahan galian (batu) hasil penambangan

Pemanfaatan bahan galian ketika dalam proses penambangan sangat penting dalam menjaga lingkungan sekitar. Ketika banyak tailingnya atau entropu berarti dalam proses penambangan kurang efektif dan efisien. Tailing cenderung akan mengakibatkan pencemaran lingkungan baik di sekitar daerah penambangan maupun di luar daerah penambangan. Tailing yang tidak termanfaatkan berpotensi tererosi dan tertransportasi ke badan air yang kemudian tersedimentasi. Adanya sedimentasi ini akan menyebabkan pendangkalan badan air dan meningkatkan suspensi sedimen sehingga kualitas air sungai dapat berkurang.

Tabel 10. Kategori \& Harkat Pemanfaatan Bahan Galian

\begin{tabular}{clcc}
\hline No & \multicolumn{1}{c}{ Pemanfaatan Bahan Galian } & Kategori & Harkat \\
\hline 1. & Tailing, $75-100 \%$ & Sangat Buruk & 1 \\
2. & Tailing, $50-75 \%$ & Buruk & 2 \\
3. & Tailing, $25-50 \%$ & Sedang & 3 \\
4. & Tailing, $0-25 \%$ & Baik & 4 \\
5. & Semua batuan termanfaatkan & Sangat baik & 5 \\
\hline
\end{tabular}

\section{3) Tahap Pasca Penambangan}

a) Upaya Reklamasi

Reklamasi merupakan salah satu kegiatan yang dilakukan sepanjang tahapan usaha pertambangan untuk menata, memulihkan dan memperbaiki kualitas lingkungan, ekologi dan ekosistem agar dapat berfungsi kembali sesuai peruntukannya. Kegiatan reklamasi pada lahan pasca tambang diharapkan dapat menata dan memperbaiki kembali lahan yang terganggu akibat kegiatan penambangan menjadi lahan yang masih bisa dimanfaatkan kembali bagi lingkungan sekitarnya. Adanya reklamasi di daerah penambangan merupakan jaminan adanya keberlanjutan peruntukan lahan sehingga tidak menjadi daerah yang tandus. Dengan demikian kegiatan penambangan dengan upaya reklamasi memiliki nilai yang baik dan berharkat 3 .

Tabel 11. Kategori \& Harkat Upaya Reklamasi

\begin{tabular}{llll}
\hline No & \multicolumn{1}{c}{ Upaya Reklamasi } & Kategori & Harkat \\
\hline 1 & $\begin{array}{l}\text { Tidak ada upaya reklamasi saat proses penambangan berlangsung } \\
\text { atau sesudah proses penambangan selesai, lahan didiamkan } \\
\text { terbengkalai. }\end{array}$ & Buruk & 1 \\
2 & $\begin{array}{l}\text { Belum ada upaya reklamasi selama proses penambangan, tetapi } \\
\text { ada rencana reklamasi setelah aktivitas penambangan selesai }\end{array}$ & Sedang & 2 \\
3 & $\begin{array}{l}\text { Reklamasi sudah diterapkan dengan perencanaan yang baik } \\
\text { bersamaan dengan pelaksanaan penambangan }\end{array}$ & Baik & 3 \\
\hline
\end{tabular}

(Sumber: Kep. Gubernur DIY No. 63 Tahun 2003)

\section{4) Aspek Kesehatan dan Keselamatan Kerja (K3)}

a) Pemakaian Alat Proteksi Diri (APD)

APD merupakan salah satu cara dalam melindungi diri dari sebuah kecelakaan kerja. Adanya kepedulian dalam menggunakan APD dapat meminimalkan risiko kerja sehingga pekerja tambang dapat melakukan aktivitas penambangan tanpa adanya kekhawatiran karena kejadian kecelakaan kerja dapat terjadi sewaktu-waktu. APD yang bisa dipakai oleh penambang rakyat misalnya adalah alas kaki (sepatu/sandal), pelindung kepala (topi/helm/caping) dan kacamata untuk melindungi serpihan bahan galian. Dengan demikian jika penambang menggunakan APD maka diberi harkat 3 dan jika tidak memakai APD diberi harkat 1.

Tabel 12. Kategori \& Harkat Pemakaian Alat APD

\begin{tabular}{lccc}
\hline No & Pemakaian Alat APD & Kategori & Harkat \\
\hline 1 & Tidak memakai & Buruk & 1 \\
2 & Tidak Lengkap & Sedang & 2 \\
3 & Lengkap & Baik & 3 \\
\hline
\end{tabular}


b) Kemiringan bidang dinding galian

Dinding galian adalah pinggiran lubang atau tebing secara menyeluruh dari permukaan sampai dasar lubang penggalian. Untuk menjaga stabilitas bidang galian, kemiringan bidang galian secara umum dibatasi maksimun $50 \%$ dan harus dibuat berteras-teras. Setiap teras tediri dari tebing teras dan dasar teras sebagai parameter yang diamati. Menurut Keputusan Gubernur DIY No.63 Tahun 2003 menjelaskan bahwa lereng galian yang baik adalah dengan kemiringan $<15^{0}$. Adapun harkat kemiringan bidang galian sebagai berikut:

Tabel 13. Kategori \& Harkat Kemiringan Bidang Galian

\begin{tabular}{cccc}
\hline No & Kemiringan Bidang Galian & Kategori & Harkat \\
\hline 1 & Buruk, bila lereng tebing galian $>22,5^{\circ}$ & Buruk & 1 \\
2 & Sedang, bila lereng tebing galian $15-22,5^{\circ}$ & Sedang & 2 \\
3 & Baik, bila lereng tebing galian $<15^{\circ}$ & Baik & 3 \\
\hline
\end{tabular}

(Sumber: Kep. Gubernur DIY No. 63 Tahun 2003)

c) Tinggi dinding galian

Dinding galian adalah pinggiran tanah secara menyeluruh dari permukaan tanah sampai puncak tebing.Untuk menjaga stabilitas dinding galian, kemiringan lereng dinding galian dibatasi maksimum $50 \%$ dan harus dibuat jenjang. Sedangkan tinggi tebing jenjang dibatasi maksimum $3 \mathrm{~m}$ sehingga terjaga batas toleransi bagi keamanan lingkungan sekitarnya. Sedangkan lebar dasar teras minimum $6 \mathrm{~m}$ untuk mempertahankan kemiringan dinding galian tidak lebih curam 50\% (Kepmen Lingkungan Hidup No.43 Tahun 1996). Adapun harkat tinggi dinding galian sebagai berikut:

Tabel 14. Kategori \& Harkat Tinggi Dinding Galian

\begin{tabular}{llll}
\hline No & Tinggi Dinding Galian & Kategori & Harkat \\
\hline 1 & Buruk, bila tinggi dinding galian $>4 \mathrm{~m}$ & Buruk & 1 \\
2 & Sedang, bila tinggi dindinggalian $3-4 \mathrm{~m}$ & Sedang & 2 \\
3 & Baik, bila tinggi dinding galian $<3 \mathrm{~m}$ & Baik & 3 \\
\hline
\end{tabular}

(Sumber: Kep. Gubernur DIY No. 63 Tahun 2003)

\section{Klasifikasi Kelayakan Teknis}

Langkah selanjutnya setelah memperoleh harkat adalah menentukan klasifikasi untuk mendapatkan kriteria kelayakan teknis dari total harkat. Adapun hasil kriteria tersebut dapat di lihat pada Tabel 15 untuk kelayakan teknis kegiatan penambangan di perbukitan. Tabel tersebut menjelaskan bahwa kelayakan teknis kegiatan penambangan diklasifikasikan menjadi 3 kelas, yaitu tidak layak, kurang layak, dan layak.

Tabel 15. Klasifikasi Kelayakan Teknis Penambangan

\begin{tabular}{lll}
\hline No. & Total Harkat & Klasifikasi \\
\hline 1. & $1,0-1,76$ & Tidak layak \\
2. & $1,77-2,53$ & Kurang layak \\
3. & $>2,53$ & Layak \\
\hline
\end{tabular}


Untuk mempermudah memahami alur kegiatan penelitian ini, maka disajikan diagram alir penelitiatan sebagai berikut :

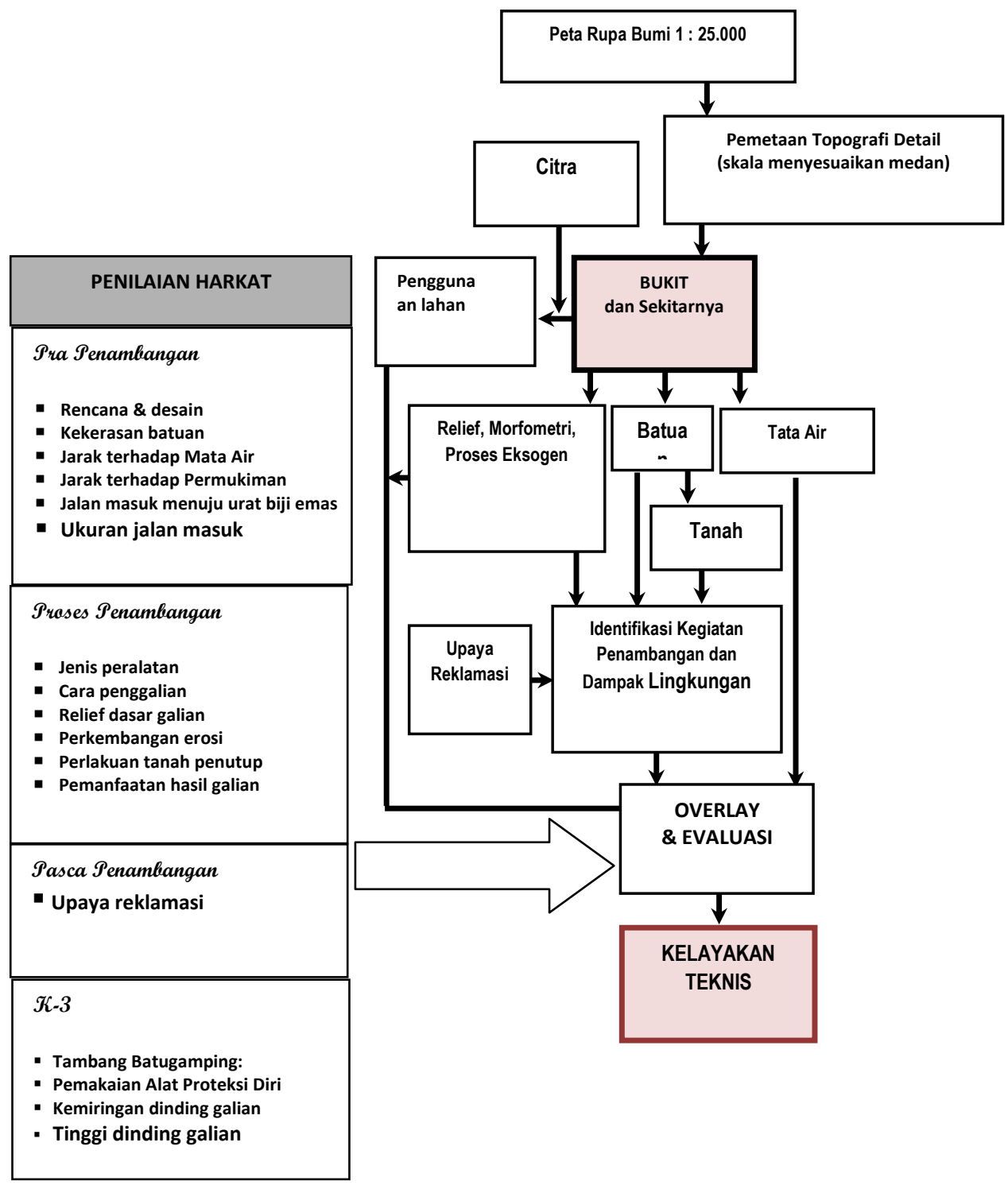

Gambar 2. Diagram Alir Penelitian

\section{HASIL DAN PEMBAHASAN}

Kegiatan penambangan batugamping dilakukan di Desa Sedangsari Kecamatan Pengasih. Kegiatan penambangan rakyat ini dilakukan pada bentuk lahan bukit. Lokasi penambangan rakyat batugamping terdapat di 2 lokasi yaitu di Dusun Paingan, Desa Sendangsari dan 1 lokasi Dusun Secang, Desa Sendangsari. Sesuai dengan Peraturan Daerah Kabupaten Kulon Progo No. 1 tahun 2012 Pasal 48 ayat (5) huruf e, dimana kawasan peruntukan tambang batugamping, meliputi: Kecamatan Pengasih, Sentolo, Lendah, Girimulyo, Temon, Kalibawang, Nanggulan, dan Samigaluh. Parameter yang digunakan untuk penilaian kelayakan teknik penambangan batugamping pada lahan bukit berupa rencana dan desain penambangan, kekerasan batuan, jarak terhadap mata air, jarak terhadap permukiman, jenis peralatan penambangan, relief dasar galian, cara penggalian, perkembangan erosi, perlakuan terhadap tanah penutup, pemanfaatan bahan galian hasil penambangan, upaya reklamasi, pemakaian alat proteksi diri, kemiringan bidang galian dan tinggi dinding galian. Evaluasi kelayakan teknis penambangan rakyat batugamping di Desa Sedangsari dirangkum dalam Tabel 16. 
Tabel 16. Kelayakan Teknis Penambangan Batugamping di Desa Sendangsari

\begin{tabular}{|c|c|c|c|c|c|c|c|}
\hline \multirow{3}{*}{ No } & \multirow{3}{*}{$\begin{array}{l}\text { Kelayakan } \\
\text { teknik }\end{array}$} & \multicolumn{6}{|c|}{ Lokasi } \\
\hline & & \multicolumn{2}{|c|}{ Dusun Paingan (PS1) } & \multicolumn{2}{|c|}{ Dusun Paingan (PS2) } & \multicolumn{2}{|c|}{ Dusun Secang } \\
\hline & & $\begin{array}{c}\text { Nilai/ } \\
\text { karakter }\end{array}$ & Harkat & $\begin{array}{c}\text { Nilai/ } \\
\text { karakter }\end{array}$ & Harkat & $\begin{array}{c}\text { Nilai/ } \\
\text { karakter }\end{array}$ & Harkat \\
\hline 1 & $\begin{array}{l}\text { Rencana dan desain } \\
\text { penambangan }\end{array}$ & tidak ada & 1 & tidak ada & 1 & tidak ada & 1 \\
\hline 2 & Kekerasan batuan & 100 mpa (baik) & 4 & $\begin{array}{l}100 \mathrm{mpa} \\
\text { (baik) }\end{array}$ & 4 & $\begin{array}{l}100 \mathrm{mpa} \\
\text { (baik) }\end{array}$ & 4 \\
\hline 3 & $\begin{array}{l}\text { Jarak terhadap } \\
\text { mataair }\end{array}$ & 1 km (baik) & 3 & $1 \mathrm{~km}$ (baik) & 3 & $1 \mathrm{~km}$ (baik) & 3 \\
\hline 4 & Jarak rumah & 19,3 m (buruk) & 1 & $5,1 \mathrm{~m}$ (buruk) & 1 & $\begin{array}{l}26,3 \mathrm{~m} \\
\text { (buruk) }\end{array}$ & 1 \\
\hline 5 & $\begin{array}{l}\text { Jenis peralatan } \\
\text { penambangan }\end{array}$ & $\begin{array}{l}\text { cangkul, betel, } \\
\text { linggis, palu } \\
\text { (baik) }\end{array}$ & 3 & $\begin{array}{l}\text { cangkul, } \\
\text { betel, linggis, } \\
\text { palu (baik) }\end{array}$ & 3 & $\begin{array}{l}\text { cangkul, betel, } \\
\text { linggis, palu } \\
\text { (baik) }\end{array}$ & 3 \\
\hline 6 & Cara penggalian & $\begin{array}{l}\text { memotong } \\
\text { tebing }\end{array}$ & 3 & $\begin{array}{l}\text { memotong } \\
\text { tebing }\end{array}$ & 3 & $\begin{array}{l}\text { memotong } \\
\text { tebing }\end{array}$ & 3 \\
\hline 7 & Relief dasar galian & $>1 \mathrm{~m}$ (buruk) & 2 & $>1 \mathrm{~m}$ (buruk) & 2 & $>1 \mathrm{~m}$ (buruk) & 2 \\
\hline 8 & $\begin{array}{l}\text { Perkembangan } \\
\text { Erosi }\end{array}$ & $\begin{array}{l}\text { sheet erosion } \\
\text { (baik) }\end{array}$ & 3 & $\begin{array}{l}\text { sheet erosion } \\
\text { (baik) }\end{array}$ & 3 & $\begin{array}{l}\text { sheet erosion } \\
\text { (baik) }\end{array}$ & 3 \\
\hline 9 & $\begin{array}{l}\text { Perlakuan terhadap } \\
\text { tanah penutup }\end{array}$ & $\begin{array}{l}\text { dimanfaatkan,(s } \\
\text { edang) }\end{array}$ & 2 & $\begin{array}{l}\text { Dimanfaatkan } \\
\text { (sedang) }\end{array}$ & 2 & $\begin{array}{l}\text { tidak } \\
\text { dimanfaatkan, } \\
\text { hilang (buruk) }\end{array}$ & 1 \\
\hline 10 & $\begin{array}{l}\text { Pemanfaatan bahan } \\
\text { galian (batu) hasil } \\
\text { penambangan }\end{array}$ & $\begin{array}{l}\text { semua } \\
\text { batubatugampin } \\
\text { g termanfaatkan } \\
\text { (baik) }\end{array}$ & 5 & $\begin{array}{l}\text { semua } \\
\text { batubatugamp } \\
\text { ing } \\
\text { termanfaatkan } \\
\text { (baik) }\end{array}$ & 5 & $\begin{array}{l}\text { semua } \\
\text { batubatugamp } \\
\text { ing } \\
\text { termanfaatkan } \\
\text { (baik) }\end{array}$ & 5 \\
\hline 11 & Upaya Reklamasi & $\begin{array}{l}\text { tidak ada } \\
\text { (buruk) }\end{array}$ & 2 & $\begin{array}{l}\text { tidak ada } \\
\text { (buruk) }\end{array}$ & 2 & $\begin{array}{l}\text { tidak ada } \\
\text { (buruk) }\end{array}$ & 2 \\
\hline 12 & $\begin{array}{l}\text { Pemakaian alat } \\
\text { APD }\end{array}$ & $\begin{array}{l}\text { tidak memakai } \\
\text { (buruk) }\end{array}$ & 1 & $\begin{array}{l}\text { tidak } \\
\text { memakai } \\
\text { (buruk) }\end{array}$ & 1 & $\begin{array}{l}\text { tidak } \\
\text { memakai } \\
\text { (buruk) }\end{array}$ & 1 \\
\hline 13 & $\begin{array}{l}\text { Kemiringan bidang } \\
\text { galian }\end{array}$ & $75^{\circ}$ (buruk) & 1 & $75^{\circ}$ (buruk) & 1 & $75^{\circ}$ (buruk) & 1 \\
\hline \multirow[t]{4}{*}{14} & $\begin{array}{l}\text { Tinggi dinding } \\
\text { galian }\end{array}$ & 4,46 m (buruk) & 1 & 3,6 m (buruk) & 1 & $\begin{array}{l}13,82 \mathrm{~m} \\
\text { (buruk) }\end{array}$ & 1 \\
\hline & Jumlah & & 32 & & 32 & & 31 \\
\hline & Nilai & 2,29 & & 2,29 & & 2,21 & \\
\hline & $\begin{array}{l}\text { Kelas Kelayakan } \\
\text { teknik }\end{array}$ & Kurang Layak & & Kurang Layak & & Kurang Layak & \\
\hline
\end{tabular}

Sumber : Evaluasi Data Lapangan, 2016

Berdasarkan Tabel 16, dapat dilihat hasil observasi dan pengukuran parameter-parameter yang digunakan sebagai penilaian kelayakan teknis penambangan batugamping. Pada parameter rencana dan desain penambangan di semula lokasi penambangan yaitu Dusun Paingan (PS1 dan PS2) dan Dusun Secang didapatkan informasi bahwa kegiatan penambangan berjalan tanpa ada suatu konsep dan perencanaan setelah kegiatan penambangan. Hal ini menyebabkan nilai harkat pada parameter desain penambangan menjadi sangat rendah atau bernilai 1. Pada parameter kekerasan batuan setelah dilakukan pengukuran didapatkan untuk ketiga lokasi penambangan memiliki nilai kekerasan batuan sebesar masing-masing 100 mpa. Hal ini menunjukkan bahwa nilai tersebut sangat baik untuk dilakukan kegiatan penambangan batuan sehingga diberikan nilai harkat 4. Pada parameter jarak terhadap mata air atau sumber air, setelah dilakukan pengukuran dan pengamatan semua lokasi penambangan memiliki jarak terhadap mata air di atas $1 \mathrm{~km}$, sehingga diberikan harkat 3 dengan kategori baik. 


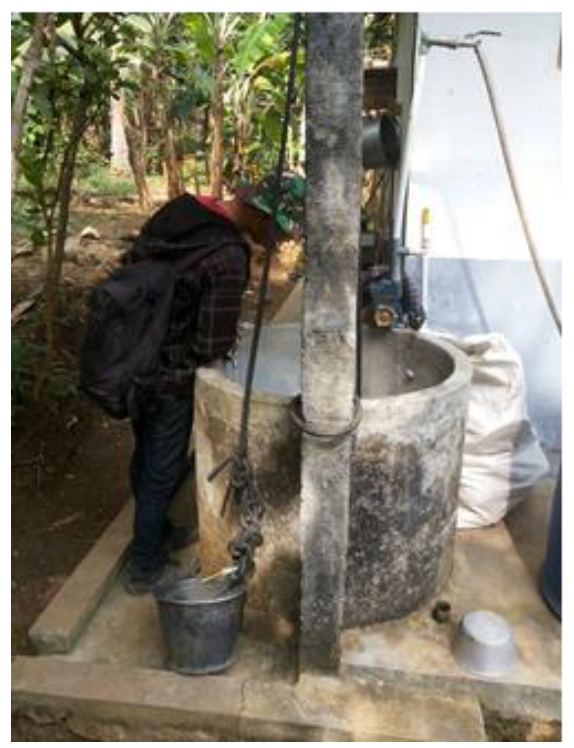

Gambar 3. Kondisi Sumber Air Tanah di Sekitar Penambangan

Jarak pemukiman dengan lokasi penambangan di Dusun Paingan adalah \pm 19,3 m dan 5,1 m. Sedangkan jarak lokasi penambangan di Dusun Secang adalah $\pm 26,3 \mathrm{~m}$. Kondisi ini dapat dinilai buruk karena kurang dari $500 \mathrm{~m}$. Jika demikian maka kondisi permukiman di sekitar penambangan batugamping berpotensi untuk tidak aman dari bencana akibat kegiatan penambangan (misalnya erosi dan gerakan massa tanah). Metode penambangan yang digunakan pada semua lokasi adalah memotong tebing dengan manual. Alat-alat yang digunakan untuk penambangan adalah alat-alat manual seperti cangkul, betel, linggis dan palu. Sehingga pada parameter jenis peralatan penambangan dan parameter cara penggalian diberikan harkat dengan nilai 3.

Pada parameter relief dasar galian diketahui bahwa semua lokasi kegiatan penambangan memiliki relief dasar galian sebesar >1 m yang termasuk dalam kategori (buruk), sehingga diberikan nilai harkat 1. Pada parameter perkembangan erosi ditemukan pada ketiga lokasi penambangan berupa sheet erosion sehingga diberikan nilai harkat 3 dengan kategori baik.

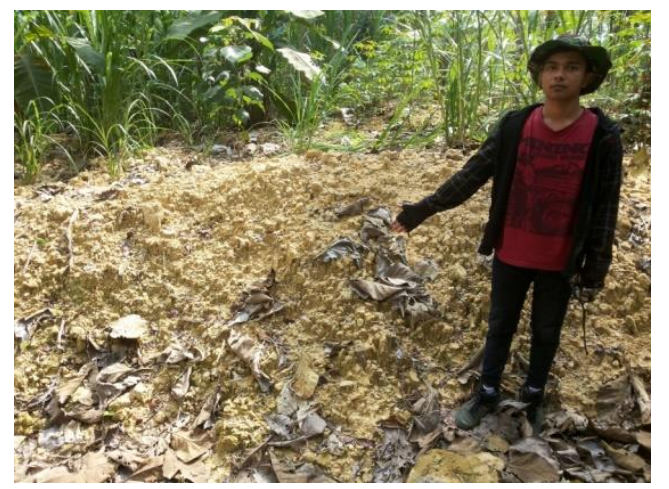

Gambar 4. Kenampakan Sheet Erosion di Sekitar Lokasi Penambangan

Parameter perlakuan terhadap tanah penutup pada penambangan batugamping di Dusun Paingan (PS1) termasuk dalam kategori sedang karena tanah langsung digunakan untuk peruntukan yang lain sehingga diberikan harkat dengan nilai 2. Sedangkan dua lokasi yang lain yaitu Dusun Paingan 2 dan Dusun Secang kondisi tanah penutp tidak dimanfaatkan atau hilang sehingga diberikan harkat 1 dengan kategori buruk. 


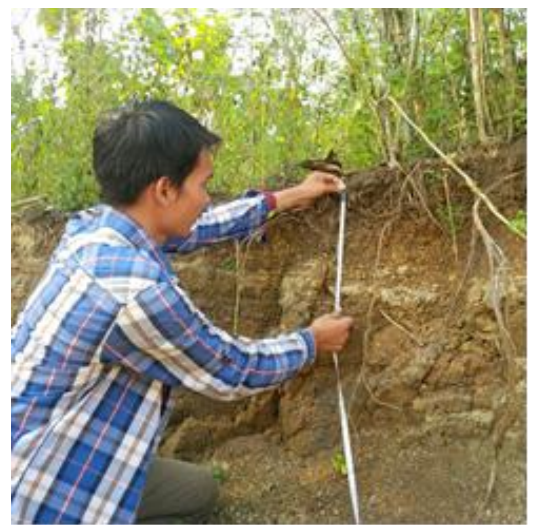

Gambar 5. Pengukuran Ketebalan Tanah

Pada parameter pemanfaatan bahan galian (batu) hasil penambangan, diketahui pada semua lokasi kegiatan penambangan semua material batubatugamping termanfaatkan sehingga diberikan harkat dengan nilai 5 dan masuk dalam kategori baik. Batugamping biasa dimanfaatkan oleh masyarakat untuk bahan pondasi bangunan, pondasi jalan, pondasi kolam ikan dan lain sebagainya.

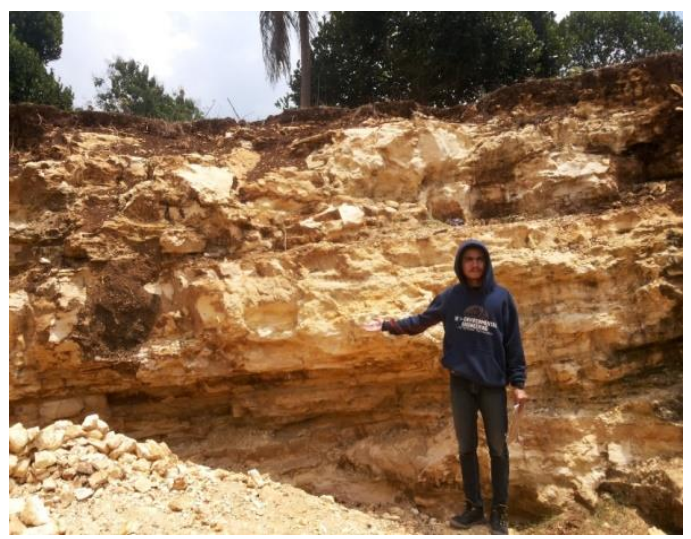

Gambar 6. Kenampakan Dinding Galian Batugamping di Lokasi Penambangan

Pada parameter upaya reklamasi berdasarkan wawancara dan pengamatan di lapangan diketahui bahwa pada semua lokasi kegiatan penambangan tidak ada upaya reklamasi sehingga diberikan harkat dengan nilai 2 dan termasuk dalam kategori buruk.

Pada parameter pemakaian alat APD diketahui pada semua lokasi kegiatan penambangan batugamping tidak menggunakan APD yang dipersyaratkan seperti tidak menggunakan pelindung kepala dan pelindung kaki sehingga dinilai dengan kondisi buruk dengan harkat 1. Pada parameter selanjutnya yaitu parameter kemiringan bidang galian diketahui ketiga lokasi kegiatan penambangan batugamping memiliki rata-rata nilai $75^{\circ}$ sehingga diberikan nilai harkat 1 dengan kategori yang buruk. Tinggi dinding galian pada penambangan batugamping di Dusun Paingan termasuk dalam kategori yang sedang dengan ketinggian 4,46 m dan 3,6 m. Sedangkan tinggi dinding galian di Dusun Secang adalah 13,82 m sehingga dikategorikan buruk.

Secara umum dapat diketahui bahwa terdapat beberapa parameter yang dinilai buruk secara teknis pada semua lokasi penambangan rakyat pasir diantaranya tidak adanya rencana dan desain penambangan, tidak menggunakan APD, kemiringan bidang galian dan jarak terhadap permukiman yang cukup dekat dengan lokasi penambangan. Pada semua lokasi kegiatan penambangan batugamping tidak memiliki rencana dan desain penambangan yang baik. Hal ini sesuai dengan kondisi eksisting di lapangan banyak ditemui bekas-bekas penggalian dinding pada tebing galian yang tidak teratur. Jarak permukiman dinilai buruk karena sangat dekat dengan lokasi penambangan baik di Dusun Paingan maupun di Dusun Secang. Berdasarkan evaluasi kondisi di atas, kegiatan penambangan batugamping semua lokasi baik di Dusun Paingan dan Dusun Secang dinilai "kurang layak" secara teknis.

Berdasarkan kondisi tersebut diatas perlu adanya arahan pola dan teknis penambangan agar lokasi-lokasi penambangan batugamping tersebut menjadi layak untuk dilakukan penambangan secara teknis. 


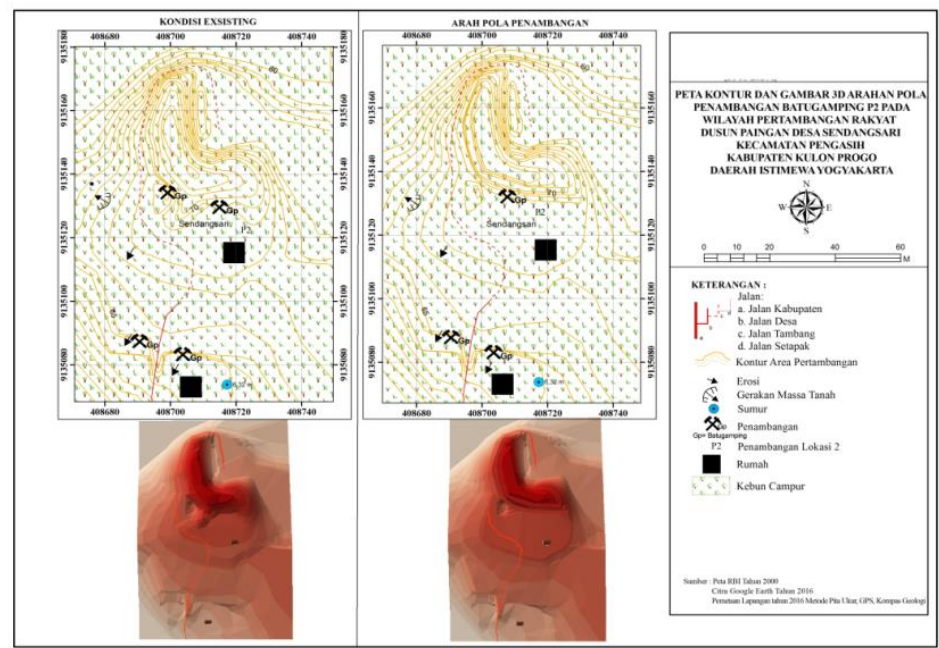

Gambar 7. Peta Kontur dan Gambar 3D Arahan Pola Penambangan Batugamping Pada WPR Dusun Paingan, Desa Sendangsari, Kec. Pengasih

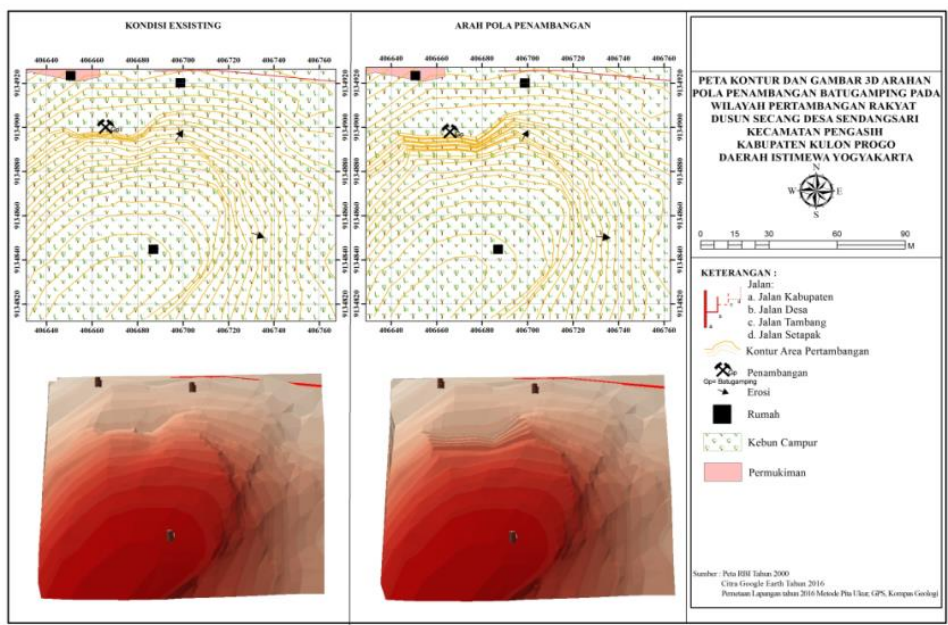

Gambar 8. Peta Kontur dan Gambar 3D Arahan Pola Penambangan Batugamping Pada WPR Dusun Secang, Desa Sendangsari, Kecamatan Pengasih

Arahan pola dan teknis penambangan batugamping di Dusun Paingan dan Dusun Secang perlu dilakukan dengan konsep perencanaan yang baik. Konsep perencanaan tersebut nantinya akan memudahkan untuk tahapan reklamasi atau revegetasi setelah dilakukan penambangan. Pola penambangan yang disarankan adalah membentuk terasering atau sengkedan atau terasbangku berdasarkan kondisi dan pola kontur yang ada. Dengan pola terasering diharapkan akan mempermudah revegetasi pada saat dilakukan reklamasi. Selain itu dengan pola tersebut akan menghindari terjadinya erosi atau longsor. Secara teknis berdasarkan analisis diatas perlu kiranya dilakukan beberapa hal berikut :

1. Dibuatnya rencana desain penambangan sebagaimana Gambar 7 dan Gambar 8.

2. Dibuatnya perencanaan reklamasi pasca penambangan

3. Para pekerja tambang disarankan menggunakan APD secara lengkap seperti caping/helm (pelindung kepala), pakaian lengan panjang, sarung tangan dsb.

4. Optimalisasi pemanfaatan tanah pucuk terutama untuk reklamasi.

5. Untuk penambangan selanjutnya perlu diusahakan tinggi dinding galian $<3 \mathrm{~m}$, lereng tebing galian $<15^{\circ}$, batas kedalaman galian sama dengan ketinggian topografi terendah sekitarnya. 


\section{KESIMPULAN}

Kegiatan penambangan rakyat batugamping terdapat di 4 lokasi dengan kondisi eksisting 3 lokasi aktif (masih dilakukan kegiatan penambangan) terdapat di Dusun Paingan, Desa Sendangsari, Kecamatan Pengasih dan Dusun Secang, Desa Sendangsari, Kecamatan Pengasih dan 1 lokasi tidak aktif (tidak ada kegiatan penambangan) yaitu di Dusun Secang. Berdasarkan evaluasi kondisi eksisting pada kajian kelayakan teknis penambangan, kegiatan penambangan batugamping pada semua lokasi baik di Dusun Paingan atau Dusun Secang dinilai "kurang layak" secara teknis dengan nilai harkat 2,29 (Dusun Paingan 1 \& 2) dan 2,21 (Dusun Secang). Disarankan ada arahan pola dan teknis penambangan sesuai dengan aturan yang berlaku agar kegiatan penambangan batugamping dapat layak secara teknis.

\section{UCAPAN TERIMA KASIH}

Ucapan terimakasih sebesar-besarnya penulis sampaikan kepada Kepala Dinas PUP-ESDM DIY - Pemda DIY beserta jajarannya dan masyarakat penambang batugamping di Desa Sendangsari, Kecamatan Pengasih, Kabupaten Kulon Progo atas segala bantuan dan partisipasinya sehingga dapat terwujud tulisan ini.

\section{DAFTAR PUSTAKA}

Arif. 2007. Perencanaan Tambang Total Sebagai Upaya Penyelesaian Pesoalan Lingkungan Dunia Pertambangan, Universitas Sam Ratulangi, Manado.

Keputusan Gubernur Propinsi Daerah Istimewa Yogyakarta Nomor 63 Tahun 2003 tentang Kriteria Baku Kerusakan Lingkungan Bagi Usaha dan/atau Kegiatan Penambangan Bahan Galian Golongan C di Wilayah Propinsi Daerah Istimewa Yogyakarta.

Khanna, N. 1999. Turmeric Natures Precious Gift, Current Science, 76, p. 1351- 1356.

Lenzen M. and Murray S.A. 2003. The Ecological Footprint - Issues and Trends. Sydney: The University of Sydney.

Noor. 2006. Geologi Lingkungan. Yogyakarta: Graha Ilmu.

Soemarwoto. 1994. Ekologi, Lingkungan Hidup dan Pembangunan, Djambatan, Yogyakarta.

Soerjani et. al. 1987. Lingkungan: Sumber Daya Alam dan Kependudukan dalam, Pembangunan. Jakarta: Penerbit Universitas Pendidikan Indonesia.

Sulton, A. 2011. Dampak Aktivitas Pertambangan Bahan Galian Golongan C Terhadap Kondisi Kehidupan Masyarakat Desa. (Skripsi) Fakultas Ekologi Manusia Institut Pertanian Bogor.

Soemarwoto. 2001. Ekologi, Lingkungan dan Pembangunan. Jakarta: Djambatan.

Sugiyono. 2017. Metode Pendekatan Peneltian Kuantitatif, Kualitatif, dan R\&D. Alfabeta, Bandung. 